\title{
Criminal Law Policy on the Protection of Children from Underage Marriage
}

\author{
Edo Fernando* \\ University of Jember, Indonesia
}

\begin{abstract}
Children as people belonging to vulnerable groups need protection in their growth and development, one of which is protection from underage marriages. Ironically, Indonesia is in a state of underage marital emergency. Normatively, the Child Protection Act places the role of parents in preventing underage marriages. On the other hand, the Marriage Law facilitates underage marriage through the parents' right to submit marriage dispensations. So, normatively there is a dualism of the role of parents in protecting children from underage marriages. This article examines the conflict between marital dispensation norms and parental obligation norms to prevent underage marriages as well as criminal law policies on child protection from underage marriages from the perspective of the Child Protection Act. Based on a literature review, the marriage dispensation norm that puts parents as applicants for marriage dispensation is contrary to the role of parents to prevent underage marriages in child protection efforts. This is because underage marriages are practices that must be prevented. After all, they place children in dangerous conditions and violate children's rights. Meanwhile, the criminal law policy against children from underage marriages in the Child Protection Act is not explicitly and explicitly accommodated. This article ends with a suggestion to regulate the protection of children from underage marriages explicitly and specifically in the Marriage Law and the Child Protection Act.
\end{abstract}

KEYWORDS: Criminal Law Policy, Underage Marriage, Child Protection.

Submitted: 12/02/2020 Reviewed: 14/02/2020 Accepted: 10/03/2020

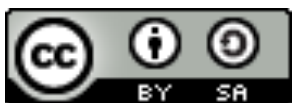

Copyright (C) 2020 by Author(s)

This work is licensed under a Creative Commons Attribution-ShareAlike 4.0 International License. All writings published in this journal are personal views of the authors and do not represent the views of this journal and the author's affiliated institutions.

*Corresponding authors' e-mail: edofernando1405@yahoo.com 


\section{INTRODUCTION}

Children are those who are before 18 years old including those who are still in the womb. ${ }^{1}$ Children are contained within the rights of children who need to be protected as creatures that are still small and weak. Protection of children's human rights is important because, on the one hand, children belong to vulnerable groups, but on the other hand, children are the capital of sustainable development. One of the protections needed by children is protection from underage marriages. Ironically, Indonesia is now in a situation of underage marital emergencies. The observation of the United Nations International Children's Emergency Fund (UNICEF) ranks Indonesia 7 th in the world ${ }^{2}$ and 2nd in ASEAN after Cambodia. ${ }^{3}$ Deputy Minister for Child Growth and Development Ministry of Women's Empowerment and Child Protection, Lenny N Rosalin said 1 out of 9 girls married under the age of 18 years or around 375 girls per day are forced to marry early. ${ }^{4}$ The analysis of underage marriages for the Central Statistics Agency (BPS) in 2016 showed that in the period 2008-2015, the number of underage marriages reached $25 \%$, meaning that it was relatively stable and there was no significant decrease. ${ }^{5}$

Underage marriages are harmful practices for children ${ }^{6}$ and violate children's rights. ${ }^{7}$ Children's rights that tend to be neglected and even violated include

Law No. 35 of 2014 on the Amendment to Law No. 23 of 2002 on Child Protection.

Nuriwan Trihendrawan. "Indonesia Ranks Seven Cases of Child Marriage", online: $<$ https://nasional.sindonews.com/read/1254271/15/indonesia-performing-t Tujuhkasus-perak-anak-1509711401>.

3 CNN Indonesia, "United Nations Highlights Number of Child Marriage in Indonesia," online: <https://www.cnnindonesia.com/style-life/20170207162847277-191868/pbb-soroti-jotal-perikah-anak-di-indonesia?>.

4 Kabar Bisnis, "Indonesia is Considered a Child Marriage Emergency," online: $<$ http://kabar24.bisnis.com/read/20171120/15/711034/indonesia-di-generatedinformation-perkawinan-a>.

5 CNN Indonesia, supra note 3.

6 Yusuf Hanafi. The Controversy of Child Marriage Under the Perspective of Islamic Jurisprudence, International Human Rights, and National Law (Bandung: CV Mandar Maju).

7 Nawal M Nour. "Child Marriage: A Silent Health and Human Rights Issue" (2009) 2 Rev Obstet Gynecol 52. 
the right to health, the right to be free from violence, as well as the right to education, and adequate livelihoods. In the aspect of health, the Ministry of Health studies that child marriages are 4.5 times as dangerous as potential reproductive harm, at risk of pregnancy (fetal brain damage and developmental disorders of children born), until death. ${ }^{8}$ The results of the Demographic and Health Survey of Indonesia (IDHS) show the Maternal Mortality Rate (MMR) in Indonesia is higher than that of many countries in ASEAN equal to 359 per 100,000 live births. ${ }^{9}$ Regarding the right to be free from violence, it turns out that underage marriages are vulnerable to violence. The Indonesian Women's Coalition states that underage marriages are the most common entry point for violence. ${ }^{10} \mathrm{~A}$ marriage that occurs at vulnerable school-aged children also inhibits children from accessing and getting an education. Data on the National Socio-Economic Survey (SUSENAS) in 2015 showed that the number of underage marriages was vulnerable to those who graduated from junior high school by $41.5 \%$, followed by elementary school graduates reaching $40 \%$ and high school graduates by $8.83 \%$. If they want to continue post-marriage school, generally, the school prohibits married children from continuing school. ${ }^{11}$ When children's education is stopped, another dangerous impact is decent work that is entitled to the child. The results of UNICEF's analysis stated that women who married at an early age worked more in the informal sector $(68.6 \%)$ and agriculture (41.4\%) than the formal sector $(31.4 \%){ }^{12}$

8 HukumOnline, "Early Marriage Is Judged Violating Girls' Rights," online: hukumonline.com

<http://www.hukumonline.com/berita/baca/lt543f9219071a8/perikah-diniinvaluedlanggarhak-anak-perempuan>.

9 Independen.ID, "Lost Access Because of Marriage at Children's Age," online: $<$ http://independen.id/read/data/479/hilang-akses-lantaran-menikahdi-usia-anak/>. VOA Indonesia, "Child Marriage Practices Trigger Violence Against Women," online: VOA Indonesia <https:/www.voaindonesia.com/a/practical-consumptionchildren-picu- violence-/3628402.html>.

11 Harnas, "Early Marriage Vulnerable School Dropouts," online: harnas.co <http://www.harnas.co/2016/07/22/nikah-dini-rentan-putus-school>.

12 Metrotvnews. "The Negative Impact of Early Marriage," online: $<$ http://rona.metrotvnews.com/ k health/nbweBgBK-dampak-negatif-perikah-usiaini $>$. 
Children as an inseparable part of the survival of humans and the nation and state are entitled and need to be protected. This protection is intended to realize children's welfare by providing guarantees for the fulfillment of children's rights without discriminatory treatment. ${ }^{13}$ In this regard, the government has issued a policy in the form of legislation related to child and marriage protection through Law No. 1 of 1974 on Marriage (Marriage Law) and Law No. 35 of 2014 on the Amendment to Law No. 23 of 2002 on Child Protection (Child Protection Act).

Marriage Law as a lex specialis related to marriage, has set the age of marriage. Article 7 paragraph (1) limits the age of marriage to a minimum of 19 years for male candidates and a minimum of 16 years for female candidates. Marriage can still occur even if one or both candidates do not meet the minimum age limit as Article 7 paragraph (1) of the Marriage Law, namely through an application for marriage dispensation by parents to the Religious Court. ${ }^{14}$ This means that marriage dispensation provides a way to facilitate underage marriages, whereas the Child Protection Act mandates to prevent underage marriages because they are vulnerable to violating children's rights and injuring child protection efforts. Also, the submission of marriage dispensation in the Marriage Law does not accommodate the minimum age limit, and the reasons/conditions for marriage dispensation are granted to make marriage dispensation easier without considering the best interests of the child.

While protecting children from underage marriages, the Child Protection Act does not regulate underage marriages expressly and comprehensively. The Child Protection Act only emphasizes that parents have an obligation and responsibility to prevent children from underage marriages. However, this arrangement is not accompanied by sanctions if the obligations and responsibilities are not carried out. In connection with if there is no criminal offense in underage marriages, to date, the positive criminal law in Indonesia,

13 Law No. 35 of 2014 concerning Amendments to Law No. 23 of 2002 concerning Child Protection.

14 Law Number 1 of 1974 concerning Marriage. 
both the Criminal Code and the laws and regulations that lex specialis, have not yet regulated the conduct of underage marriages. ${ }^{15}$ Underage marriage arrangements that are still not comprehensive even contradictory between the Marriage Law and the Child Protection Act have the effect of making it easier for children to be in a situation of underage marriages, and children who have been married are vulnerable to being protected by their rights.

There are two fundamental issues examined in this article. First, does Article 7 paragraph (2) of the Marriage Law contradicts Article 26 paragraph (1) letter $\mathrm{c}$ of the Child Protection Act in protecting children's efforts? Second, what is the criminal law policy in providing child protection from underage marriages in the perspective of the Child Protection Act? This type of research to study the problems in this article is the research of statute and conceptual approaches.. In order to solve legal issues at the same time prescribe what should be, the sources of legal materials used include primary legal materials and secondary legal materials. Primary legal material consists of the Child Protection Act and the Marriage Law. Secondary legal material includes publications on a law that are not official documents, such as legal textbooks/literature, legal journals. The legal materials are then analyzed by steps, including identifying legal facts, eliminating irrelevant matters, and establishing legal issues; The collection of legal materials; examine the proposed legal issues; draw conclusions that address legal issues, and provide a prescription.

\section{THE MARRIAGE ACT VS THE CHILD PROTECTION ACT}

Children are part of legal subjects that play a strategic role in the nation and state. In essence, children cannot protect themselves from a variety of actions that cause mental, physical, social harm in various fields of life and livelihood.

15 Supriyadi \& Yulkarnain Harahap. "Underage marriages in the perspective of criminal law and Islamic law" (2009) 21: 3 Mimb Huk 599. 
So that children need protection so as not to suffer losses both mentally, physically, and socially. ${ }^{16}$

Basically, legal protection for children is an effort to protect two things, namely fundamental rights and freedoms of children and interests related to children's welfare.$^{17}$ In the perspective of human rights, children are part of vulnerable groups ${ }^{18}$ so that they are entitled to treatment and protection that are more relevant to their specificities, Human Rights Reference mentions seven groups that are included in vulnerable groups, namely: a. refugees, b, Internally Displaced Persons (IDPs); c. national minorities, d. migrant workers; e. indigenous peoples, f. children; and g. women. ${ }^{19}$

As a manifestation, the protection of children is a part of the development agenda as outlined in the policy in the form of laws and regulations. The laws and regulations in Indonesia that specifically regulate the legal basis for child protection are the Child Protection Act. In the case of underage marriages, the Child Protection Law mandates parents to prevent their children from marrying at the age of the child as stipulated in Article 26 paragraph (1c). The following provision, Article 26 paragraph (2), regulates the transfer of parental obligations and responsibilities.

"In the event that parents are absent, or their whereabouts are unknown, or for some reason they cannot carry out their obligations and responsibilities, the obligations and responsibilities referred to in paragraph (1) may be transferred to the family, which is carried out under statutory provisions. "

Regarding underage marriages, the United Nations has campaigned massively that underage marriages are harmful to traditional practices, ${ }^{20} \mathrm{a}$

16 Maidin Gultom. Legal Protection of Children and Women (Medan: Refika Aditama, 2012).

17 Waluyadi. Child Protection Law (Bandung: Mandar Maju, 2009).

18 Law Number 39 of 1999 concerning Human Rights (Article 5 paragraph (3).

19 Willem van Genugten JM, "Human Rights Reference" (1994) Hague Neth Minist Foreign Aff 73.

20 Yusuf Hanafi, supra note 6. 
tradition that reflects the values and beliefs held by the community over many generations, in which some This tradition provides benefits for members of the community but some others are harmful to certain groups, such as children. ${ }^{21}$ Interestingly, although this traditional practice has a dangerous impact and is even contrary to human rights, this practice still survives and is even more widespread. Besides, the United Nations and other international institutions agree and declare that underage marriages violate human rights and children's rights. ${ }^{22}$ This agreement was later declared in several international conventions consisting of the Universal Declaration of Human Rights (UDHR), the Convention on the Right of the Child (CRC), and the Convention on the Elimination of All Forms of Discrimination against Women (CEDAW).

In the UDHR's view, marriage is required to have the right to freedom and full agreement from both parties to be married. ${ }^{23}$ The terms of the agreement to get married must come from the two candidates who will marry, not from the other party. While according to the $\mathrm{CRC}$, the minimum age for marriage for both men and women is 18 (eighteen) ${ }^{24}$ Moreover, the CRC does not tolerate marriages under the age of 18 years. Like the UDHR and CRC, CEDAW, as a convention aimed at women as part of vulnerable groups, does not allow underage marriages. Because in practice, underage marriages are more common in girls and harm the rights of girls. As the results of the International Plan and Coram International research in 3 countries, namely Bangladesh, Pakistan, and Indonesia, the number of underage marriages is

21 Ibid.

22 Nawal M. Nour, supra note 7.

23 (a) Men and women of full age..., have the right to marry and to found a family. They are entitled to equal rights as to marriage, during the marriage, and at its dissolution. (b) Marriage shall be entered into only with the free and full consent of the intending spouses. See Article 16 of the Universal Declaration of Human Rights.

24 A child means every human being below the age of eighteen years unless, under the law applicable to the child, the majority is attained earlier. See Convention on the Rights of the Child. 
mostly done by girls, except in Pakistan, the highest number of underage marriages is performed by boys. ${ }^{25}$

Smith in Yusuf Hanafi stated that children's rights are at the heart of international human rights instruments (Comprehensive including civil and political, economic, social and cultural rights, the indivisibility and universality of the United Nations human rights system are at the heart of children rights). ${ }^{26}$ Thus, the protection of children from underage marriages through prevention by parents shows the importance of protecting children's rights.

Article 26 paragraph (1), which continues in paragraph (2), regulates the transfer of parental obligations and responsibilities. There are three reasons for the transfer of parental responsibilities and obligations according to the provisions of this article, namely because of the absence of parents, because the parents are not known, and because they cannot carry out their obligations and responsibilities. The provisions of Article 26 paragraph (2) are not accompanied by provisions in matters such as whether parents or parties who have transferred the obligations and responsibilities stated or deemed unable to carry out the obligations, and how the legal consequences of the transfer of obligations and responsibilities. That the Child Protection Act has mandated parents to prevent underage marriages as part of child protection efforts, ironically, other regulations provide deviations for underage marriages, namely marriage dispensation regulated in Article 7 of the Marriage Law.

(1) Marriage is only permitted if the man has reached the age of 19 (nineteen) years and the woman has reached 16 (sixteen) years;

25 Plan International, "Getting the Evidence: Asia Child Marriage Initiative Summary Report” (2016) 1.

26 Yusuf Hanafi, supra note 6. 
(2) In the case of irregularities in paragraph (1), this article may request a dispensation from the Religious Courts or other officials requested by both male or female parents.

The norms of marriage dispensation and the obligation of parents to prevent underage marriages both involve the role of parents. Article 26 paragraph (1c) of the Child Protection Act involves the role of parents to prevent underage marriages, while Article 7 paragraph (2) involves the role of parents to propose marriage dispensations so that marriages that are not old enough can take place. Consequently, dualism arises from the role of parents in the perspective of the Marriage Law and the Child Protection Act.

Concerning child protection efforts, marriage dispensation tends to conflict with the obligation of parents to prevent underage marriages as child protection efforts. When parents apply for a dispensation, marriage at the Religious Courts and the judges are granted. However, if there are things that are proven to be harmful to the child in the future, then there is a conflict between marriage dispensation and the obligation of parents to prevent child marriage.

It was mentioned earlier that in addition to conflicting with international conventions, underage marriages became contrary to the obligations of parents to prevent underage marriages as an effort to protect children because of underage marriages, so they were vulnerable to neglect and violated children's rights. Essential aspects of marriage that affect the realization of marriage goals, namely the physical and psychological aspects of candidates who will get married. Regarding physical aspects, this aspect is especially essential for girls, because of the phases of pregnancy and childbirth. Both phases require a healthy physique and are ready to undergo the process so that the baby is born healthy, and the mother's condition is also healthy. However, the age of the child is an age that is not feasible/competent to reach the phase of pregnancy and childbirth. In UNICEF's view, pregnancy at the age of a child is not recommended because reproductive functions performed under the age of 20 years are at high risk of developing the disease resulting 
in death. ${ }^{27}$ The risk of contracting the disease until death occurs because humans experience a phased growth that strategy is at the age of 12-19 years and in fetuses aged the last four months. In both phases, adequate nutrition becomes a necessity. The age of the pregnant mother and the fetus both need nutrition, so there is a struggle for nutrition. When the baby's nutritional intake is not met, then the baby is born imperfect, brain development is not perfect, low body weight to experience disability. If maternal nutrition is inadequate, then it results in eclampsia, bleeding, and even death. ${ }^{28}$ When adverse impacts on the mother and child still in the womb occur, this violates the rights of the child in protecting children in the health sector as stipulated in the Child Protection Act, namely the right to be cared for and cared for from the womb, ${ }^{29}$ the right to be protected from acts that disturb the child's health and child development ${ }^{30}$ and protection rights from diseases that threaten the survival and/or disability of children. ${ }^{31}$

In addition to physical aspects, psychological aspects also play an important role in marriage. In adolescence, mental and emotional status is immature and tends to be unstable. ${ }^{32}$ Mental maturity plays an important role because, in marriage, there are consequences for new roles and responsibilities, namely as husband and wife to parents. Psychic immature and unstable in living a domestic life can trigger domestic violence (domestic violence). The Ministry of Women's Empowerment and Child Protection (KPPPA) states that the increasing trend of domestic violence is in line with the increase in underage marriages, which are considered as triggers. ${ }^{33}$ Likewise, Lori L. Heise stated that girls who get married early are very vulnerable to domestic

27 Decision of the Constitutional Court Number 30-74/PUU-XII/2014 [Constitutional Court Decision Number 30-74/PUU-XII/2014].

Ibid.

Child Protection Act, supra note 13.

Ibid.

Ibid.

Decision of the Constitutional Court Number 30-74 / PUU-XII / 2014, supra note 28.

Media Indonesia. "Early Marriage Vulnerable Triggers Domestic Violence" (11 October 2016), online: <http://mediaindonesia.com/read/detail/71508-perikah-dinirentan-picu-kdrt>. 
violence, harassment, and neglect. ${ }^{34}$ Adverse conditions affecting children as a result of underage marriages, which are not supported by mature psychological aspects, injure the protection of children's rights in the social field, namely the right to protection from various ill-treatment. ${ }^{35}$

The marriage world, which gives rise to new roles and responsibilities, turns out to be vulnerable in eliminating the roles that children should play in their developmental age. The role of children, especially girls, is often overlooked due to underage marriages, namely education. UNICEF research results show a correlation between the age of marriage and the level of education that women who are married under age tend to have low levels of education and vice versa, women with higher education levels tend to get married over the age of 18 (eighteen) years. ${ }^{36}$ The practice of underage marriages, which results in the loss of the opportunity for children to get an education, violates the protection of children in the field of education, namely the right to get an education in the framework of development ${ }^{37}$ and the right to get the most extensive education. ${ }^{38}$

Marriage dispensations that end in marriages tend to conflict with the prevention of parents to prevent underage marriages as child protection efforts. Moreover, legally marriage dispensation has not been regulated, comprehensively especially regarding the minimum age limit, and the terms of marriage dispensation are granted. According to Mardi Candra, marriage dispensation in the Marriage Law has not prioritized children's interests and not under the objectives of child protection. ${ }^{39}$

Underage marriages that occur through marriage dispensation cannot be blamed because marriage dispensation itself has its arrangements. However,

34 Heise, LJ Pitanguy \& A Germain, "Violence Against Women: The Hidden Health Burden.” (1994) World Bank Wash DC 255.

35 "Law Number 23 of 2002 concerning Child Protection".

36 UNICEF, "Ending Child Marriage Progress and Prospects" 3.

37 Child Protection Act, supra note 13.

38 Ibid.

39 Mardi Candra. Aspects of Indonesian Child Protection Analysis of Underage Marriage, first ed (Jakarta: Prenada Media, 2018). 
the harmful effects that befall children due to underage marriages also cannot be left alone because, in addition to endangering children, underage marriages are dangerous for the community. Therefore, in order to protect children who receive marriage dispensation, marriage dispensation should be regulated by containing child protection. Mardi Candra provides the concept of marriage dispensation that breathes child protection, namely: ${ }^{40}$ First, involving the full and maximum role of children in the management of the case for the determination of marriage dispensations in the Religious Courts. Second, the process of marriage dispensation proceedings should be conducted in private. Third, norms governing child protection and marriage dispensation must strictly stipulate the criteria for children who can be given marriage dispensation for minors. Fourth, norms governing child protection and marriage dispensation must set a minimum age limit for marriage dispensation. Fifth, regulate the guarantee of parents or guardians of children against underage marriages. Sixth, contains norms that can create synchronization and harmonization between the Child Protection Act and the Marriage Law so that child protection can be realized in marriage dispensation in the Court.

\section{CRIMINAL LAW POLICY IN PROVIDING CHILDREN PROTECTION FROM UNDER MARRIAGE}

\section{A. Child Protection from Underage Marriage}

The Child Protection Act has regulated the obligations and responsibilities of parents to prevent minors from underage marriage, as referred to in Article 26. In practice, parents have a role and involvement and become a driver in the marriage of their underage children. According to Gynecol in Santosh K. Mahato, there are three main reasons parents force their children to marry

$40 \quad$ Ibid. 
young, namely (1) poverty, (2) social pressure; and (3) beliefs offer protection. ${ }^{41}$

Underage marriages often occur in families with a lower-middle economy. For them, this practice is believed to be a way to reduce the family's economic burden. Parents assume that children, especially girls, are a burden to the family. Girls are expensive in terms of food, clothing, and education. In the end, they are not enjoyed by the family but brought in household life. Even in the case of dowry, underage marriages are considered to avoid increasing the dowry's value because it only applies to higher education to get a higher dowry value.

"Dowry perpetuates child marriage as it encourages parents to marry off their girls early to avoid an increase in the dowry amount (more educated girls usually require a higher dowry). Girls are considered an economic burden for their family of origin and a "parayadhan" or property that belongs to the marital family. Hence, the tendency is to marry girls as early as possible and reduce investment in their daughters. Investing in girls' education is not considered worthy as girls will be moved to the groom's household and will be employed in household chores. On the other hand, girls' limited education and livelihood options lead to marriage being one of the few options for girls' futures." 42

Besides, parents encourage underage marriages for fear that if their child does not get married soon, be considered an old maid. Even marrying a young girl is believed to be a way to maintain the child's virginity and purity.

"There was a common belief among parents that marrying the daughters of young should protect them from rape, premarital sexual activity, unintended pregnancy, and sexually transmitted infections, especially human immunodeficiency virus (HIV) and AIDS." ${ }^{43}$

41 Santosh K Mahato, "Causes and Consequences of Child Marriage: A Perspective" (2016) 7:7 Int J Sci Eng Res 700. 
One case of underage marriages that occurred at the instigation of parents is an underage marriage between Lutviana Ulfah and HM Pujiono Cahyo.W. The motive of Lutviana Ulfah's father, Suroso, allowed his underage son to marry Pujiono Cahyo, owner of the Miftahul Jannah Islamic Boarding School and Brass Entrepreneur from PT. Silenter (Sinar Lendoh Terang), is so that he and his family get facilities and various kinds of benefits and even raise the family's economic status. In this case, Ulfa's parents know that their child is underage and not yet married. However, because he was tempted by HM Pujiono Cahyo.W's economic status, Suroso did not prevent the marriage. Based on the Ambarawa District Attorney Indictment Letter No. Reg. Perk: PDM-63 / 0.3.42 / Ep.2 / 10/2009, Lutviana Ulfa's father's involvement in his marriage was considered economic exploitation (Article 88 of the Child Protection Act) and facilitated the occurrence of obscene acts (290 2nd KUHP Jo article 56 to -2 Criminal Code). ${ }^{44}$

However, the involvement of parents in underage marriages violates children's rights and conflicts with obligations as Article 26 paragraph (1c) of the Child Protection Act is not given sanctions as a legal consequence. In fact, according to Hans Kelsen, legal obligations and responsibilities must be done and, if not done, impose sanctions on the holders of obligations and responsibilities. ${ }^{45}$ However, sanctions for the negligence of these obligations and responsibilities are not found in the Child Protection Act. The Child Protection Act is limited to the transfer of obligations and responsibilities when parents cannot carry out for specific reasons.

Child protection from underage marriages later in the Child Protection Act, namely the protection of children's rights, both general and specific. Protection, in general, is regulated in Chapter IX concerning Implementation of Protection, which covers protection in the religious field (Articles 42-43), protection in the health sector (Articles 44-47), protection in education (Articles 48-54), and protection in the social field (Articles 55-

${ }_{44}$ Pandu Lesanpura Aji. Review of Criminal Law on Parental Involvement in the Occurrence of Child Marriage (Case Study in the Ambarawa District Attorney), (Thesis, Sebelas Maret University, 2010) [unpublished].

45 Hans Kelsen. General Theory of Law and State (Bandung: Nusa Media, 2015). 
58). The implementation of child protection is specifically regulated in Articles 59-71B.

In the context of protecting children from underage marriages, it is not found that underage marriages as part of the protection are entitled to children in general. Underage marriages, aside from potentially robbing and violating children's rights in the field of public protection, also have the potential to violate children's rights in the field of special protection. In connection with special protection, this protection is given in certain situations and conditions that serve to guarantee a sense of security against threats that endanger the child and his life in development. ${ }^{46}$ There are fifteen specific situations and conditions formulated in the Child Protection Act as part of special child protection efforts. The fifteen special protections are given to (a) children in an emergency situation; (b) Children in conflict with the law; (c) children from minority and isolated groups; (d) Children who are exploited economically and/or sexually; (e) children who are victims of narcotics, alcohol, psychotropic, and other addictive substances; (f) children who are victims of pornography; $(\mathrm{g}$ ) children with HIV/AIDS; (h) Child abducted, sold and/or trafficked; (i) child victims of physical and/or psychological abuse; $(j)$ child victims of sexual crimes; $(k)$ child victims of terrorism networks; (l) children with Disabilities; (m) child victims of mistreatment and neglect; (n) children with deviant social behavior and (o) children who are victims of stigmatization from labeling are related to the condition of their parents. ${ }^{47}$ Of the fifteen situations and conditions, underage marriages are not part of either the other articles or the explanation of the Child Protection Act. Underage marriages are vulnerable to placing children in situations that endanger them and their lives during their growth and development. Situations are vulnerable to threaten children include violence, exploitation, lost opportunities to get the most extensive education, proper health, and develop themselves.

\footnotetext{
46 Child Protection Act, supra note 1. 
Because special protection provides protection measures comprehensive for children, two forms of protection offered in special protection are a protection to prevent and avoid children in certain situations (preventive) and protection when children become victims, which includes healing the victim and sanctions for the perpetrator (punishment). An example is the protection of children who are exploited economically and/or sexually. Preventive protection measures are carried out through efforts to disseminate and/or disseminate provisions of laws and regulations relating to the Protection of Children who are exploited economically and/or sexually; involving various companies, trade unions, nongovernmental organizations, and the community in eliminating economic and/or sexual exploitation of children. ${ }^{48}$ If a child has been victimized, efforts will be made to the perpetrators, namely monitoring, reporting, and giving sanctions. ${ }^{49}$ Even acts of economic and / or sexual exploitation of children are specifically formulated in the criminal provisions of the Child Protection Act. ${ }^{50}$

From the perspective of the ius constitutum, underage marriages are related to two things, first, can underage marriages qualify as a crime in the Child Protection Act? Second, can underage marriage practices that violate children's rights be enshrined in the Child Protection Act? It turns out, besides not being classified as special protection as a right that is entitled to children, underage marriages that violate children's rights and place children in dangerous conditions are not expressly and regulated in the comprehensively Child Protection Act. Even because of the current national criminal law, there is also no explicit prohibition of underage marriages. ${ }^{51}$

The formulation of a criminal act in the criminal provisions of the Child Protection Act separates the norms and sanctions. Chapter XIA on

48 Ibid.

49 Ibid.

50 Every person who is refused, permitted, committed, ordered to do, or participated in full economic and / or sexual exploitation of children. Every person who violates the provisions as referred to in Article 76I, will be sentenced to a maximum of 10 (ten) years and / or a maximum fine of Rp. 200,000,000.00 (two hundred million rupiah). Ibid.

51 Supriyadi \& Yulkarnain Harahap, supra note 16. 
Prohibition contains ten types of criminal acts which are accommodated in Articles 76A-76J and sanctions regulated in Articles 77-90. Of the ten crimes regulated, two are relevant to underage marriages, namely violence and economic and/or sexual exploitation.

The Child Protection Act defines violence as any act against a child that results in physical, psychological, sexual, and/or neglect or suffering, including threats to commit acts, coercion, or deprivation of liberty unlawfully. The new definition accommodates the classification of violence but without the accompanying definition of each type of violence. Whereas for children who get violent in marriage, it will be easier to be ensnared by Law No. 23 of 2004 concerning the Elimination of Domestic Violence (PKDRT Law) because the regulation is specifically constructed to regulate violence that occurs in the scope of households. The PKDRT Law provides more protection for victims than the Child Protection Act. Because the PKDRT Law accommodates the rights of victims, protection of victims, and recovery of victims explicitly. Even the criminal provisions regulate the types of violence in detail and provide additional crimes. Unlike the PKDRT Law, the Child Protection Act, in addition to formulating violence without being accompanied by a definition of each type of violence, turns out that sanctions for each type of violence are equated. Even the Child Protection Act only provides criminal sanctions to offenders without regulating the protection of child victims as an effort to improve their physical and psychological health.

The next crime related to underage marriage is exploitation, especially economic and sexual exploitation. Like the regulation of violence, the Child Protection Act only regulates the prohibition and sanction of committing criminal acts of sexual and economic exploitation. Article 76I mandates that "Everyone is prohibited from placing, allowing, committing, committing to do, or participating in economic and/or sexual exploitation of Children." Whereas in national law, the criminal act of exploiting children is a concept that has not been widely discussed, especially in the scope of criminal law.

Existing exploitation arrangements are not more specific in regulating the exploitation of children, especially those that occur in marriage. Plus, the 
arrangements are still scattered in several laws and regulations, namely the Criminal Code, Law No. 21 of 1997 concerning Eradication of Trafficking in Persons (UU TPPO), Law no. 35 of 2014 concerning Amendments to Law No. 23 of 2002 concerning Child Protection (Child Protection Act), Law No. 10 of 2012 concerning Ratification of the Optional Protocol to the Convention on the Rights of the Child Concerning Child Sales, Child Prostitution, and Child Pornography, Presidential Decree No. 36 of 1990 concerning the Convention on the Rights of the Child (CRC), Presidential Decree No. 87 of 2002 concerning the National Action Plan for the Elimination of Commercial Sexual Exploitation of Children. Of the six regulations, only the TPPO Law provides a definition of sexual exploitation, but the definition does not cover economic exploitation and is not specific to children in marriage.

If related to explicit meaning? The exploitation that occurs in a marriage, the formulation of the most criminal offense, is Article 288 of the Criminal Code. Article 288 of the Criminal Code states that anyone who marries in copulation with a woman he knows or deserves must be assumed that he is not yet married if resulting in injury is threatened with a maximum of four years in prison. If someone results in serious injuries, she/he will be sentenced to a maximum of eight years in prison, and If the result of death is a maximum sentence of imprisonment of twelve years.

Based on these provisions, Article 288 can be applied to intercourse in marriages where such marriages take place based on a dispensation from the Religious Courts. The result of such intercourse if there are injuries, serious injuries, until the death of women who have not been married. The things that endanger children due to underage marriages are not only intercourse that results in injury. Thus, article 288 of the Criminal Code cannot protect children in marriage if the consequences are acts other than violence. 


\section{B. What's Children Next Protection?}

The protection from underage marriage, as mentioned in the current Child Protection Act, has not been fully able to protect children, including those in marriage and if it has occurred due to marriages that endanger children, such as violence and exploitation. Criminal law policy is part of a criminal policy that functions to overcome crime through legal efforts (penal) aimed at achieving public welfare. Talking about the upcoming criminal law policy is closely related to criminalization, namely the policy to establish an action that was not originally a criminal offense into a criminal act. Central in handling crime through the means of penalties, there are two things: determining what actions should be used as a criminal offense and what sanctions should be imposed on violators.

In conducting criminalization must be careful and carried out carefully. The National Criminal Law Reform Symposium formulates general criteria for criminalization, including: First, acts that will be criminalized are acts that are disliked or hated by the community because of their adverse nature, bring victims, or can bring victims. Second, the cost of criminalizing is balanced with the results to be achieved, meaning that efforts ranging from rulemaking, supervision to enforcement are balanced with the legal order to be achieved. Third, it does not cause overbelasting, which is an imbalance between law enforcement officers' ability and burden. Fourth, the acts to be criminalized obstruct the nation's ideals and pose a danger to the whole community.

Based on the four criteria established by the National Legal Development Agency, it turns out that underage marriages do not meet the criteria for criminalization. First, actions that will be criminalized are not only harmful but are also hated by the community. This becomes a dilemma for underage marriages. Because some people still believe that underage marriages are not despicable even aimed at looking after children, even though some other communities do not want to because the consequences are dangerous for children and society at large. Second, efforts to minimize the practice of underage marriages are still a formidable challenge, take a long time, as well 
as high costs, and are even feared to cause overbelasting. Please note that the cost of crime prevention requires a large budget, and based on the fifth UN Congress, the costs are higher than the government administration budget. Thus, J. Andenaes, in Barda Nawawi Arief reminded that basing criminal law as a concept of community protection should develop as rationally as possible, which is balanced in terms of costs and results and effectiveness in terms of criminal sanctions. According to Ted Honderich, a criminal is said to be an economic deterrent if it meets three conditions, namely: (1) the criminal indeed prevents; (2) the criminal does not create a more dangerous/detrimental condition than would occur if the criminal was not imposed; and (3) there is no other criminal offense that can prevent it effectively with a smaller harm/loss.

Third, other conditions that have not met the criteria for criminalization are criminalized acts that are contrary to the morality, religion, and morals of Pancasila. In this case, underage marriages are often used to prevent pregnancy by marriage (married by accident) in children where married by accident is considered contrary to religious norms and decency. So it is not surprising that one of the posita that parents often ask for marriage dispensation is to prevent children from getting pregnant before marriage (married by accident). Thus, underage marriages that occur through marriage dispensation on the grounds to avoid acts that violate religious or moral norms do not meet the criteria, as stated by Barda Nawawi Arief. Fourth, the step of criminalization is also hampered by the characteristics and principles of limiting criminal law. Criminal law is a subsystem of social control facilities that are unable to overcome the problem of crime as a complex human and social problem (socio-psychological, socio-political, socioeconomic, socio-cultural, and so on). These limitations place the use of criminal law in combination with other efforts outside criminal law. Someone should use other sufficient facilities that are lighter first because criminal law is inherent as the ultimate means (ultimum remedium). In addition, there are limiting principles to not regulation restrictions that do not have strong support from the public. From the things that have been described and explained above, it states that Indonesia is in an underage 
marital emergency, indicating that this practice is still not supported by the community if it is used as a crime.

Even though marriages below still do not fulfill procedures for criminalization, the Child Protection Act as a regulation that protects children explicitly should regulate child protection comprehensively, meaning that it protects from any actions that can endanger the rights and welfare of children. As according to Peter Newel, those children need protection for their existence due to: (a) costs to make a recovery due to failure to provide protection is very high. Much higher than the costs incurred to obtain protection; (b) children are very influential directly and long-term for the action (action), or not doing the action (inaction) from the government or other groups; (c) children always experience gaps in the delivery of public services; (d) children do not have voting rights nor have the power of lobbying to influence government policy agendas; (e) children, in many circumstances, cannot access the protection and compliance of children's rights; (f) children are more at risk of exploitation and abuse.

It is necessary to improve the Child Protection Act in regulating child protection from underage marriages about underage marriages that can hamper child protection. There are three things related to marriage that should be formulated in the coming Child Protection Act, including, among others. First, it includes "children with underage marriages" as a particular form of protection that children are entitled. Underage marriages should be classified as special protection as a practice that is vulnerable to physical and psychological harm to children, threatening the rights of children in their growth and development because special protection protects two sides, namely preventive and repressive. Preventive protection measures are intended to prevent underage marriages, minimize and avoid the harmful effects of marriages for children. Preventive protection is provided through the socialization of relevant laws and regulations, education to the community, counseling, assistance, and social rehabilitation. Another reason for the need for underage marriages to be part of special protection is as a guarantee of the fulfilment of children's rights in underage marriages up to 
children aged 18 (eighteen) years. Even when children are victims of crime in their marriages, special protection provides repressive protection in the form of monitoring, reporting, and providing sanctions.

Second, set sanctions for the negligence of the obligations and responsibilities of parents towards children. In Hans Kelsen's view, the form of legal obligation must be followed by legal sanctions as a consequence of not carrying out that obligation. Of course, sanctions, in this case, are not given just like that, as reminded by Herbert L. Packer to use criminal sanctions carefully and humanely. At least if the actions of parents who do not prevent underage marriages and in such marriages, the rights and welfare of children are violated. Third, regulate specifically and expressly criminal offenses relevant to underage marriages. Underage marriages as a dangerous practice for children are vulnerable to crime, including violence, exploitation, and child trafficking. However, these acts are not explicitly regulated in the Child Protection Act, while regulation still creates difficulties in its enforcement. Even in other criminal laws and regulations, no regulation of criminal acts in underage marriages has been found, except Article 288 of the Criminal Code, and that article is still limited.

\section{CONCLUSION}

The marital dispensation is contrary to the norms of parental obligations and responsibilities to prevent underage marriages because Article 26 paragraph (1c) of the Child Protection Act involves the role of parents in preventing underage marriages. However, Article 7 paragraph (2) involves the role of parents to apply for marriage dispensation so that their marriage can take place. Marriage dispensation is the legality of marital irregularities that have been carried out when they do not reach the minimum limit (underage marriages) through parents' requests to the Religious Courts. Meanwhile, the Child Protection Act mandates to prevent underage marriages because this practice is a traditional practice that endangers children and violates children's rights. 
The criminal law policy in providing child protection from underage marriages in the perspective of the Child Protection Act does not exist until now. Protection of minors from underage marriages under the current Child Protection Act covers: (1) preventive measures through the obligations and responsibilities of parents to prevent minors from marrying without being accompanied by sanctions, (2) children are entitled to general protection and specifically, but such protection does not cover protection from underage marriages, and (3) the criminal provisions of the Child Protection Act do not explicitly regulate underage marriages as criminal acts. The ideal child protection policy from underage marriages in the Child Protection Act in the future is related to criminalization. However, based on the criteria and principles of criminalization, underage marriages cannot be criminalized.

The suggestion that the author proposes is, regulates the dispensation of marriage, which contains child protection in the Marriage Law and emphasizes the regulation of underage marriages in the Child Protection Act as a special rule in the field of child protection. The formulation of marriage dispensation in the Marriage Law includes the minimum age limit for children who can be given marriage dispensation and marriage dispensation based on the best interests of the child as an effort to protect children if the marriage dispensation is granted and underage marriages occur. Also, the Child Protection Act, as a particular rule in child protection, needs to regulate underage marriages strictly and comprehensively.

\section{REFERENCES}

Barda Nawawi Arief. Criminal Law Policy Rampai: (Development of the Drafting of the New Criminal Code Concept). (Jakarta: Kencana, 2010).

Dewi Ervina Suryani. "Legal Protection of Children Victims of Sexual Exploitation in Early Marriage (Study of Indonesian Supreme Court Decision Number 690k/Pid.Sus/2010)" (2015) 3: 2 USU Law J 
98 | Criminal Law Policy on the Protection of Children from Underage Marriage

182Hans Kelsen. General Theory of Law and State (Bandung: Nusa Media, 2015).

Heise, LJ Pitanguy \& A Germain. "Violence Against Women: The Hidden Health Burden." (1994) World Bank Wash DC 255.

Herbert L Packer. The Limits of the Criminal Sanction (California: Stanford University Press, 1968).

John Kenedi. Penal Policy in the Law Enforcement System in Indonesia (Yogyakarta: Pustaka Belajar, 2017).

Lilik Mulyadi. Theoretical and Practical Perspective Criminal Law Interest, 1st ed (Bandung: PT. Alumni, 2008).

Maidin Gultom. Legal Protection of Children and Women (Medan: Refika Aditama, 2012).

Mardi Candra. Aspects of Indonesian Child Protection Analysis of Underage Marriage, first ed (Jakarta: Prenadamedia, 2018).

Nawal M Nour. "Child Marriage: A Silent Health and Human Rights Issue" (2009) 2 Rev Obstet Gynecol 52.

Pandu Lesanpura Aji. Review of Criminal Law on Parental Involvement in the Occurrence of Child Marriage (Case Study in the Ambarawa District Attorney), (Thesis, Sebelas Maret University, 2010) [unpublished].

Plan International. "Getting the Evidence: Asia Child Marriage Initiative Summary Report" (2016) 1.

Santosh K Mahato. "Causes and Consequences of Child Marriage: A Perspective" (2016) 7: 7 Int J Sci Eng Res 700.

Supriyadi \& Yulkarnain Harahap. "Underage marriages in the perspective of criminal law and Islamic law" (2009) 21: 3 Mimb Huk 599.

UNICEF. "Ending Child Marriage Progress and Prospects" 3.

Waluyadi. Child Protection Law (Bandung: Mandar Maju, 2009). 
Willem van Genugten JM. "Human Rights Reference" (1994) Hague Neth Ministry of Foreign Affairs 73.

Yusuf Hanafi. The Controversy of Child Marriage Under the Perspective of Islamic Jurisprudence, International Human Rights, and National Law (Bandung: CV Mandar Maju).

CNN Indonesia, "United Nations Highlights Number of Child Marriage in Indonesia," online: <https://www.cnnindonesia.com/style-life/201702 07162847-277-191868/pbb-soroti-jotal-perikah-anak-di-indonesia?>.

Harnas, "Early Marriage Vulnerable School Dropouts," online: harnas.co <http://www.harnas.co/2016/07/22/nikah-dini-rentan-putus-school>.

HukumOnline, "Early Marriage Is Judged Violating Girls' Rights," online: hukumonline.com <http://www.hukumonline.com/berita/baca/lt543f 9219071a8/perikah-dini-invaluedlanggarhak-anak-perempuan>.

Independen ID, "Lost Access Because of Marriage at Children's Age," online: <http://independen.id/read/data/479/hilang-akses-lantaranmenikahdi-usia-anak/>.

Kabar Bisnis, "Indonesia is Considered a Child Marriage Emergency," online:

<http://kabar24.bisnis.com/read/20171120/15/711034/indonesia-digenerated-information-perkawinan-a> .

Kompas, "Early Marriage Judged as the Root of the Problem of Trafficking in People - Kompas.com," online: <https://nasional.kompas.com/read/ 2017/03/02/17562791/perkawinan.dini.dinilai.sagai.akar.masa\%20 people trading.

Metrotvnews. "The Negative Impact of Early Marriage," online: $<$ http://rona.metrotvnews.com/k-health/nbweBgBK-dampak-negatifperikah-usia-ini>.

Media Indonesia. "Early Marriage Vulnerable Triggers Domestic Violence" (11 October 2016), online: <http://mediaindonesia.com/read/detail/ 71508-perikah-dini-rentan-picu-kdrt>. 
100 | Criminal Law Policy on the Protection of Children from Underage Marriage

Nuriwan Trihendrawan. "Indonesia Ranks Seven Cases of Child Marriage", online: <https://nasional.sindonews.com/read/1254271/15/indonesiaperforming-t Tujuh-kasus-perak-anak-1509711401>.

VOA Indonesia, "Child Marriage Practices Trigger Violence Against Women," online: VOA Indonesia <https://www.voaindonesia.com/a/ practical-consumption-children-picu- violence-/3628402.html>. 